\title{
Dietary and other factors involved in the proliferation, determination and differentiation of adipocyte precursor cells
}

\author{
BY A. CRYER, S. E. WILLIAMS* AND J. CRYER \\ Department of Biochemistry, University of Wales College of Cardiff, PO Box 903, \\ Cardiff CFI $1 S T$
}

White adipose tissue, as a specialized connective tissue, is found in a recognizable form in a wide range of animal species (Pond, 1978, 1986; Nir et al. 1988) where its contribution to lipid metabolism and energy balance is well accepted (Cryer \& Cryer, 1990). Initially, studies on the development of white adipose tissue concentrated on a description of the changes in mature adipocyte cell size and number that occur in a variety of species (for review, see Cryer \& Cryer, 1990) during growth. The findings, arising from such studies, indicate clearly that, contrary to early propositions, the cellular development that accompanies adipose tissue growth involves both cellular hyperplasia and hypertrophy at virtually all stages of life (for example, see Faust \& Miller, 1981) and that both processes can be affected by nutritional manipulation (Faust et al. 1978).

Although there has been a suggestion that fully differentiated unilocular adipocytes may proliferate under appropriate conditions in vitro, it is still the case that the overwhelming weight of evidence from studies both in vivo (Geloen et al. 1989) and in vitro (Ailhaud, 1982) supports the view that the major proliferative activity in adipose tissue is in the interstitial pool of cells which includes, as a major component, the so-called adipocyte precursor cell (Cryer, 1980; Hauner \& Loffler, 1987a,b).

At the current state of development in the field, an increasing amount of information on the nature and behaviour of the adipocyte precursor in vitro is forthcoming (for example, see Ailhaud et al. 1991: Cryer \& Cryer, 1991). However, because of the experimental difficulties, much of the relevance these findings may have to the behaviour of such cells in vivo remains to be discerned. Clearly, the precise description of the stages through which adipocyte development passes can be addressed by experimentation in vitro. In particular, the biochemical descriptions that may be adduced in vitro should, it may be speculated, provide appropriate markers which may then be applied in order to follow temporal and induced changes in the cellular development of the tissue in vivo.

Thus, the major work in the area has sought to study the effectors of adipocyte precursor proliferative activity and those factors that are essential or permissive with regard to the progression of the earlier and later stages of the differentiation programme which culminate together in the generation of a mature unilocular adipocyte (for review, see Cryer \& Cryer, 1990). Most recently, our own work has concentrated on defining the state of development of precursor cells isolated from adipose tissue taken from a variety of depots in various animal species (Cryer \& Cryer, 1989). Such animals have been at differing stages of overall development and the cells have been studied with regard to the nature of the effectors that stimulate their proliferation and differentiation in vitro. The comparative biochemistry of the latter now indicates the species-specific nature of the pattern of effectors that are active and this is described in more detail elsewhere (Adams

* Present address: Nuffield Department of Clinical Medicine, John Radcliffe Hospital, Headington, Oxford OX3 9DU. 
et al. 1992). The present paper will concentrate on current knowledge relating to the stage of development displayed by adipocyte precursors when they are derived from tissue sources in vivo.

\section{METHODS}

Putative precursor cells with the capacity to undergo adipose conversion were isolated from the white adipose tissue of rat, chicken, ox and sheep as described by Cryer $e t$ al. (1984, 1987) and Cryer \& Cryer (1989) and were maintained in culture as described therein. Mature ovine adipocytes were allowed to revert to a lipid-free proliferative form using the methods described in Cryer \& Cryer (1990).

Antisera with specific reactivity towards white adipocyte cell surface antigens were prepared, characterized and employed as described by Thompson \& Abrahams (1979), Plaas et al. (1981), Lee et al. (1986) and Cryer et al. (1987). In some experiments anti-adipocyte antibodies were labelled directly with acridinium ester using the technique described by Woodhead \& Weeks (1985). The preparation and characterization of white adipocyte plasma membranes employed the method of Belsham et al. (1980) and anti-ovine lipoprotein lipase serum was prepared as described by Al-Jafari \& Cryer (1986).

RNA was isolated from cultured cells by caesium chloride ultracentrifugation following extraction in guanidinium thiocyanate. The cells were removed from the growth surface mechanically, washed in sterile phospate buffered saline ( 9 g sodium chloride/l) and frozen in liquid nitrogen before the extraction. The RNA samples were studied using conventional methods and found to be free of DNA and protein.

Probes for the analysis of the RNA samples were prepared and utilized using standard techniques, as described by Maniatis et al. (1982) and Kille et al. (1990). The lipoprotein lipase (EC 3.1.1.34; LPL) activity of cultured cells was determined as described previously (Plaas \& Cryer, 1980).

\section{RESULTS AND DISCUSSION}

\section{Adipocyte precursor cell growth characteristics}

When adipocyte precursor cells were isolated from the white adipose tissue of a variety of species, the rate of their proliferation in the presence of serum was shown to be similar for most species (doubling time approximately $26 \mathrm{~h}$ ) and for most depot sources (K. S. Adams, D. J. Flint, R. G. Vernon and A. Cryer, unpublished results). However, the strain of the animal from which the cell may be derived (Donnelley et al. 1989) and the age of the donor (Donnelley, 1990) have been shown to have an influence, with the doubling time for cells derived from young animals being shorter than that for those isolated from mature animals. Such donor age-related differences seem not to be related to the sensitivity of the cells to growth effectors present in serum, in that such differences were also discernible when a serum-free medium of defined composition was used (A. Cryer and J. Cryer, unpublished results). However, data collected to date would suggest that there are significant differences between the species with respect to specific cell receptor specificities and responsiveness (see Adams et al. 1992).

When putative adipocyte precursor cells have been isolated from the white adipose tissue of a variety of species they have been found, under optimal conditions of culture 
Table 1. Ratio of immunoreactivity demonstrated by cells at confluency and at the maximum post-confluency level*

\begin{tabular}{lcccc} 
& & \multicolumn{3}{c}{ Adipocyte precursors from: } \\
\cline { 3 - 5 } Cells & $3 \mathrm{~T}_{3}-\mathrm{L}_{1}$ (mouse) & Rat & Sheep & Ox \\
\hline Ratio (confluency:maximum) & $0: 1$ & $0.26: 1$ & $0.51: 1$ & $0.2: 1$ \\
\hline
\end{tabular}

* Specific anti-adipocyte immunoreactivity was determined using either the indirect-labelled second-antibody cellular immunoassay previously described (Plaas \& Cryer, 1980) or, in the case of sheep, chemiluminescentlylabelled anti-adipocyte antibodies (Cryer \& Cryer, 1991). Cells at confluency were compared with those expressing maximum immunoreactivity post-confluency. The antisera used were raised on a species-specific basis.

(which varies among species), to acquire the morphological characteristics of (at least) multilocular adipocytes within approximately 14-21 d of post-confluency cell culture. Such changes in morphology are accompanied not only by increases in phenotypic enzyme activities (for example, LPL) but also by increases in the reactivity that the cells exhibit when reacted with antibodies previously shown to be adipocyte-specific (for example, see Cryer \& Cryer, 1991). These approaches have, however, both in our work and that of others, been confined to a comparison of post-confluency cells with those studied at the point of confluency. Growing cells have received scant attention, partly it may be suggested because of operational reasons and partly because cloned adipocyte precursor cell lines such as $3 T 3-L_{1}$ and others exhibit no discernible adipocyte characteristics during their growth phase in culture.

The demonstration of adipocyte characteristics by precursor cells at and before confluency

1. Adipocyte specific immunoreactivity. When adipocyte precursor cells from a number of species were compared, in respect of their species-defined adipocyte-specific immunoreactivity at confluency, with that demonstrated by $3 \mathrm{~T} 3-\mathrm{L}_{1}$ cells it was found that, unlike $3 \mathrm{~T}_{3}-\mathrm{L}_{1}$ cells, the tissue-derived precursors all exhibited adipocyte-specific immunoreactivity at confluency (Table 1) which was between 20 and $55 \%$ of that exhibited maximally by cells during the post-confluency period of culture development.

These observations were extended specifically in the case of cells from sheep where the immunoreactivity of growing cells at a variety of stages was determined. This was done, first, in relation to total antibody binding and, second, the nature of binding was investigated by studying immunoprobed blots of polyacrylamide gels loaded with plasma membrane preparations isolated from cells harvested at various stages of culture (from growing to late confluency).

When the whole cell plasma membrane immunoassay was performed it was found that, when expressed per unit cellular protein, the reactivity of growing cells, derived from five different anatomical sites of the sheep, was invariably equal to or greater than that shown by the confluent cells and was similar to that shown by cells $10 \mathrm{~d}$ after confluency (Table 2) when reactivity was associated with clear morphological evidence of differentiation.

The reactivity of the membrane preparations was then analysed by Western Blotting, in which samples were subjected to polyacrylamide gel electrophoresis in the presence of 
Table 2. Changes in anti-adipocyte-specific immunoreactivity during the growth and post-confluency maintenance of sheep adipocyte-precursor cells in culture. (From Cryer \& Cryer, 1991)

(Values expressed as percentage calculated from triplicate determinations in each case)

\begin{tabular}{lccc}
\hline \hline & \multicolumn{3}{c}{ Stage of culture } \\
\cline { 2 - 4 } Depot source & Growing & Confluent & $\begin{array}{c}10 \mathrm{~d} \\
\text { post-confluent }\end{array}$ \\
\hline Channel & 145 & 121 & 100 \\
Mesenteric & 92 & 82 & 100 \\
Subcutaneous & 79 & 64 & 100 \\
Perirenal & 69 & 76 & 100 \\
Intramuscular & 95 & 66 & 100 \\
\hline
\end{tabular}

sodium dodecyl sulphate followed by electro-transfer to an immobilization membrane (Immobilon-P Millipore UK) and reaction with antibody, the presence of the bound antibody being visualized using a peroxidase (EC 1.11.1.7)-anti-peroxidase (PAP) amplification system with 4-chloro-naphthol as chromagen. The intensity of staining obtained on such blots was compatible with the pattern revealed by the immunoassay, with the pattern of revealed bands, however, being different at each time-point studied (results not shown).

These findings are compatible with the previously reported findings obtained using fluorescent-activated cell sorting (FACS) of antibody reactive bovine adipocyte precursor cells soon after isolation from the tissue (Cryer et al. 1984). Thus, it is clear that high levels of adipocyte specific immunoreactivity exists in cultures of rapidly dividing adipocyte precursor cells and, as such, these cells appear to exhibit some adipocyte characteristics well before the later stages of the differentiation programme are entered into following growth arrest in vitro. Knowing that the adipocyte specific immunoreactivity is considered an early marker of the adipocyte phenotype (Cryer \& Cryer, 1991) further investigation of a second somewhat later marker of adipocyte function, i.e. LPL activity, was also investigated in growing cells.

2. LPL activity, immunoreactivity and messenger $R N A$ content. When $3 T 3-\mathrm{L}_{1}$ cells have been studied, LPL activity has only been demonstrated after the cells have entered the post-confluency stage of culture development. In previous studies, with tissuederived adipocyte precursors, the pre-confluency growth phase has been poorly studied, although with these cells also the activity at confluency has been shown to be low and to be followed by a dramatic post-confluence increase.

With sheep cells we have re-investigated the pattern of LPL expression in both growing and post-confluency cells by measuring activity, the presence of protein reactive with an anti-LPL antibody and the presence of RNA species able to hybridize with both labelled-RNA and cDNA specific for LPL-mRNA. The activity of LPL detected in cells at seeding, during growth, when freshly confluent and during post-confluency, the activity, calculated as a percentage of the maximal activity expressed post-confluency, was 0,87 and 9 respectively. Thus, although freshly confluent cells expressed only low levels of activity (as expected), those that were actively growing and dividing expressed comparatively high levels. This pattern was qualitatively confirmed on Western Blots of 


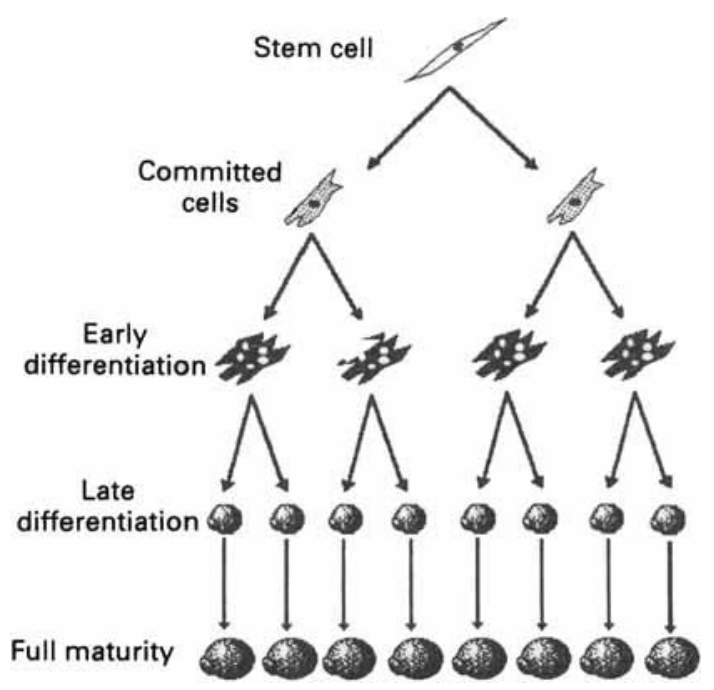

Fig. 1. Stages in adipocyte differentiation.

cellular plasma membrane preparations which were probed with anti-LPL serum followed by exposure to the PAP/4-chloro-naphthol system of visualization. This latter observation suggested that changes in the rate of synthesis of the enzyme were occurring during the maintenance of the cells in culture, rather than post-translational activity control being singularly involved. This was confirmed when the levels of LPL-mRNA were determined in the cells at the same stages of development. The determinations showed that the LPL-mRNA levels were highest in growing and post-confluent cells (where activity and immunoreactivity were also comparatively elevated) and were at their lowest following seeding and at the point of growth arrest when confluency was reached.

These findings are entirely compatible with those shown previously (p. 382) and indicate strongly that the proliferatively active precursor cell isolated from adipose tissue is highly determined during its growth phase and that it is clearly committed to the adipocyte lineage well before growth arrest, when only the later aspects of the adipocyte differentiation programme remain to be completed. A simple model of adipocyte development within adipose tissue may, therefore, be proposed (Fig 1) in which the strict division between proliferation and determination/differentiation can be eroded. However, it is clear that many problems remain to be addressed, not least of which is the definition of the earliest stages of determination and the measurement of the cell pool sizes of pluripotent stem cells, determined pre-adipocytes and adipocytes in tissue at different stages of development and a description of how such a spectrum might shift in response to nutritional change.

The financial support of the Agricultural and Food Research Council is gratefully acknowledged, as is that of the Medical Research Council for the provision of a postgraduate studentship to S.E.W. The authors are also much indebted to S. Kestin (Department of Meat Animal Science, University of Bristol) for the provision of highly characterized tissue samples and antiserum production facilities. 


\section{REFERENCES}

Adams, K. S., Flint, D. J., Vernon, R. G. \& Cryer, A. (1992). Factors stimulating proliferation of sheep adipocyte precursor cells. Proceedings of the Nutrition Society 51, 149A.

Ailhaud, G. (1982). Adipose cell differentiation in culture. Molecular and Cellular Biochemistry 49, 17-31.

Ailhaud, G., Amri, E., Barcellini-Couget, S., Bertrand, B., Catalioto, R.-M., Dani, C., Djian, P., Doglio, A., Forrest, C., Gaillard, D., Ibrahimi, A., Grimaldi, P., Negrel, R., Vannier, C. \& Vassaux, G. (1991). Biological signal triggering adipose cell differentiation. In Progress in Obesity Research 1990, pp. 201-205 [Y. Oomura, editor]. London: John Libbey and Company Ltd.

Al-Jafari, A. A. \& Cryer, A. (1986). The lipoprotein lipase of white adipose tissue. Changes in the adipocyte cell surface content of the enzyme in response to extracellular effectors in vitro. Biochemical Journal 238, 239-246.

Belsham, G. J., Denton, M. \& Tanner, M. J. A. (1980). Use of a novel rapid preparation of fat cell membrane employing Percoll to investigate the effects of insulin and adrenaline on membrane protein phosphorylation within intact cells. Biochemical Journal 192, 457-467.

Cryer, A. (1980). Adipocyte histogenesis. Trends in Biochemical Sciences 1, 196-198.

Cryer, A. \& Cryer, J. (1989). Site-related variations in the behaviour of ovine adipocyte precursor cells grown in culture. Biochemical Society Transactions 17, 1120-1121.

Cryer, A. \& Cryer, J. (1990). Regulation of structure, growth and differentiation of adipocytes. In The Control of Body Fat, pp. 19-42 [J. M. Forbes and G. R. Harvey, editors]. London: Smith-Gordon.

Cryer, A. \& Cryer, J. (1991). Comparative studies of adipocyte precursor differentiation and growth. In Progress in Obesity Research 1990, pp. 207-212 [Y. Oomura, editor]. London: John Libbey and Company Ltd.

Cryer, A., Gray, B. \& Woodhead, J. S. (1984). Studies on the characterization of bovine adipocyte precursor cells and their differentiation in vitro using an indirect labelled second antibody cellular immunoassay. Journal of Developmental Physiology 6, 159-176.

Cryer, J., Woodhead, B. G. \& Cryer, A. (1987). The isolation and characterization of a putative adipocyte precursor cell type from the white adipose tissue of the chicken (Gallus domesticus). Comparative Biochemistry and Physiology 86B, 515-521.

Donnelley, L. E. (1990). A study of factors affecting chicken adipocyte precursor development in vitro. PhD Thesis, University of Wales.

Donnelley, L. E., Butterwith, S. \& Cryer, A. (1989). Differential growth characteristics of adipocyte precursor cells derived from the white adipose tissue of the chicken (Gallus domesticus). Biochemical Society Transactions 17, 1129-1130.

Faust, I. M., Johnson, P. R., Stern, J. \& Hirsch, J. (1978). Diet-induced adipocyte number increase in adult rats: a new model of obesity. American Journal of Physiology 4, E279-E286.

Faust, I. M. \& Miller, W. H. (1981). Effects of diet and environment on adipocyte development. International Journal of Obesity 5, 593-596.

Geloen, A., Collet, A. J., Guay, G. \& Bukowiecki, L. J. (1989). Insulin stimulates in vivo cell proliferation in white adipose tissue. Journal of Lipid Research 8, 274-284.

Hauner, H. \& Loffler, G. (1987a). Adipose tissue development: I. The role of precursor cells and adipogenic factors. Klinische Wochenschrift 65, 803-811.

Hauner, H. \& Loffer, G. (1987b). Adipose tissue development: II. The role of precursor cells and adipogenic factors. Klinische Wochenschrift 65, 812-817.

Kille, P., Stephens, P. A., Cryer, A. \& Kay, J. (1990). The expression, purification and characterization of a recombinant rainbow trout metallothionein from E. coli. Biochimica et Biophysica Acta 1048, 178-186.

Lee, S., Tume, R. K., Cryer, J. \& Cryer, A. (1986). Studies on the expression of adipocyte-specific cell surface antigens during the differentiation of adipocyte precursor cells in vitro. Journal of Developmental Physiology 8, 207-226.

Maniatis, T., Fritsch, E. F. \& Sambrook, J. (1982). Molecular Cloning: A Laboratory Manual. Cold Spring Harbour, NY: Cold Spring Harbour Laboratory.

Nir, I., Nitsan, Z. \& Keren-Zvi, S. (1988). Fat deposition in birds. In Leanness in Domestic Bira's. Genetic, Metabolic and Hormonal Aspects, pp. 141-174 [B. Leclercq and C. C. Whitehead, editors]. London: Butterworths.

Plaas, H. A. K. \& Cryer, A. (1980). The isolation and characterization of bovine adipocyte precursors in culture. Journal of Developmental Physiology 2, 275-289. 
Plaas, H. A. K., Woodhead, J. S. \& Cryer, A. (1981). The use of antiserum with specific reactivity toward fat cell surface antigen(s) to follow the progression of $3 \mathrm{~T} 3-\mathrm{L}_{1}$ preadipocyte differentiation in vitro. Bioscience Reports 1, 207-216.

Pond, C. M. (1978). Morphological aspects of the ecological and mechanical consequences of fat deposition in wild vertebrates. Annual Review of Ecological Systems 9, 519-570.

Pond, C. M. (1986). The natural history of adipocytes. Scientific Progress (Oxford) 70, 45-71.

Thompson, K. \& Abrahams, S. (1979). Identification of mouse mammary adipose cells by membrane antigens. In Vitro 15, 441-445.

Woodhead, J. S. \& Weeks, I. (1985). Chemiluminescence immunoassay. Pure and Applied Chemistry 7, 523-529. 